\title{
EFFECT OF BETA IRRADIATION ON THE STRUCTURAL CHANGES OF ISOTACTIC POLYPROPYLENE
}

\author{
VPLIV RADIOAKTIVNEGA SEVANJA BETA NA STRUKTURNE \\ SPREMEMBE IZOTAKTIČNEGA PROPILENA
}

\author{
Martina Kaszonyiová, Frantisek Rybnikar, Milena Kubišová, David Maňas \\ Tomas Bata University in Zlin, Faculty of Technology, Vavreckova 275, Zlín 76001 \\ mhribova@ft.utb.cz
}

Prejem rokopisa - received: 2017-06-30; sprejem za objavo - accepted for publication: 2017-10-11

doi:10.17222/mit.2017.089

\begin{abstract}
The electron $\beta$-irradiation of isotactic polypropylene (iPP) influenced the sample chemical structure because it mostly caused the crosslinking of the polymer chains beside the macromolecule degradation. The irradiation effect led to the corresponding changes in physical properties (crystallinity, crystal size, melting and crystallisation temperatures). The amount of the $\beta$-phase in the samples decreased with the increasing $\beta$-irradiation dose, changing into the $\alpha$ - and amorphous phase. After the irradiation, the iPP melting and crystallisation temperatures decreased, and the spherulitic structure was partially decomposed. The imbibition of boiling xylene proved that the highest degree of crosslinking took place in the samples irradiated with a dose of 33 $\mathrm{kGy}$, showing the highest crystallinity and melting temperature.

Keywords: isotactic polypropylene crystal modifications, $\beta$-irradiation, structure and properties
\end{abstract}

Elektronsko radioaktivno $\beta$-obsevanje vzorcev izotaktičnega polipropilena (iPP) vpliva na njihovo kemijsko zgradbo, ker to povzroča prečno vezavo polimernih verig, povezano z degradacijo (krajšanjem) makromolekul. Vpliv obsevanja vpliva skladno $\mathrm{S}$ tem tudi na fizikalne lastnosti polimera (kristaliničnost, velikost kristalov, tališče in temperatura kristalizacije). S povečevanjem doze obsevanja $\beta$ se količina $\beta$-faze zmanjšuje zaradi njenega spreminjanja v $\alpha$ in amorfno fazo. Po obsevanju se tališče in temperatura kristalizacije iPP znižata, sferulitična (kroglična) struktura pa delno razpade. Imbibicija (razmikanje molekul) med vretjem ksilena je pokazala, da nastopa večja stopnja prečne vezave molekul pri vzorcih, ki so jih avtorji prispevka obsevali s $33 \mathrm{kGy}$ dozo, kar kaže na večjo kristaliničnost in višje tališče.

Ključne besede: kristalne modifikacije izotaktičnega propilena, radioaktivno sevanje $\beta$, struktura in lastnosti

\section{INTRODUCTION}

The properties of semicrystalline polymers prepared with usual technologies can be influenced by several factors such as time, temperature, moisture and other environmental factors, where the radiation is significant. In this contribution, we studied the effect of the $\beta$-radiation on some principal characteristics of isotactic polypropylene (iPP) and its basic structural changes. ${ }^{1-5}$

\section{EXPERIMENTAL PART}

Commercial isotactic polypropylene V-PTS-Crealen-EP-2300L1 M800 (PTS Plastic Technologie Service, Germany; MFR $\left(230^{\circ} \mathrm{C}, 2.16 \mathrm{~kg}\right)=6 \mathrm{~g} / 10 \mathrm{~min}$; $\left.\rho=0,9 \mathrm{~g} / \mathrm{cm}^{3}\right)$ containing $5 \%$ of volume fractions of a crosslinking agent (TAIC - triallylisocyanurate) enabling the crosslinking with the $\beta$-irradiation, was used. ${ }^{2}$ The tested samples were prepared with the injectionmoulding technology at a temperature in the range of $210-240{ }^{\circ} \mathrm{C}$, injection pressure of $80 \mathrm{MPa}$ and injecting rate of $50 \mathrm{~mm} / \mathrm{s}^{3}$. Subsequently, the samples were irradiated at the company BGS Beta-Gamma-Service GmbH \& Co. KG, Saal an der Donau, Germany, with electron rays, with an energy of $10 \mathrm{MeV}$ and doses of (33, 66 and 99) $\mathrm{kGy}$ in air at room temperature. ${ }^{4}$

Xylene imbibition - An experiment was carried out according to ČSN EN 5791996 to prove the iPP sample crosslinking at the degrees of imbibing $Q$ achieved by boiling xylene at $140{ }^{\circ} \mathrm{C}$ for $30 \mathrm{~min}$ and $60 \mathrm{~min}$.

Fourier transform infrared spectroscopy - An infrared analysis was made using a FTIR spectrometer Nicolet 6700 FTIR (Thermo Nicolet Instruments Co., USA). The following degradation functional groups were identified: $-\mathrm{OH}$ from the FTIR bands of $3600-3080 \mathrm{~cm}^{-1}$ and -CO- from $1800-1500 \mathrm{~cm}^{-1}$ bands.

Wide-angle X-ray scattering - Wide-angle X-ray diffraction measurements were made using the PANalytical X'Pert PRO X-ray diffraction system (Netherland) with $\mathrm{Cu}-K_{\alpha} \mathrm{Ni}$-filtered radiation. Diffraction patterns were obtained in the reflection mode in a range of $5-30^{\circ} 2 \theta\left(4.5^{\circ} 2 \theta / \mathrm{min}\right)$. The total crystallinity (X) was calculated as the ratio of the areas of crystal diffraction peaks and the total scattering area. Crystal size $L_{110}$ of the $\alpha$ most intensive peaks was calculated using the Scherrer equation. ${ }^{6}$ As the standard, perfect-crystal terephthalic-acid peak at $2 \theta=17.4^{\circ}$ and the half-maximum breadth at $0.3^{\circ} 2 \theta$ were chosen. The amounts of $\alpha$ and $\beta$ were calculated as the areas of the corresponding 
peaks $(\alpha=110,040,130$ and $\beta=300)$ from the total crystallinity. The results in Table 1 are arithmetic averages of three measurements.

Differential scanning calorimetry - The melting and crystallisation of iPP were analysed using DSC Q 100 (TA INDUSTRIES, USA) with the heating and cooling rate of $10{ }^{\circ} \mathrm{C} / \mathrm{min}$ in a $\mathrm{N}_{2}$ atmosphere. The enthalpy of fusion was $148 \mathrm{~J} / \mathrm{g}$ for $100 \% \alpha$-phase and $113 \mathrm{~J} / \mathrm{g}$ for the $\beta$-phase. ${ }^{7}$

Morphology - Sample micrographs were characterised with a transmission electron microscope Tesla BS 500 (Czech Republic) at $90 \mathrm{kV}$ using replicas of selectively etched sample surfaces. Selective etching was carried out using a 1-\% solution of $\mathrm{KMnO}_{4}$ in $85-\%$ $\mathrm{H}_{3} \mathrm{PO}_{4}$ for 1-10 min at room temperature. ${ }^{8}$ The samples were consequently gold or platinum vacuum shadowed and covered with a thin layer of vacuum-evaporated carbon. For obtaining sample replicas, a 5-\% water solution of polyacrylic acid was used. The magnification on the micrographs is indicated with $1-\mu \mathrm{m}$ bars.

\section{RESULTS AND DISCUSSION}

The samples of iPP containing $5 \%$ of volume fractions of the crosslinking agent were $\beta$-irradiated using dose intensities of (33, 66 and 99) $\mathrm{kGy}$. The sample crosslinking was confirmed by measuring the degree of imbibition $(Q)$ when boiling xylene for $30 \mathrm{~min}$ and 60 min. The crosslinked-sample network was proportional to the amount of the retained quantity of the solvent. The non-irradiated sample dissolved $(Q=0)$ after $60 \mathrm{~min}$. The sample irradiated with $33 \mathrm{kGy}$ had the largest sieve mesh $(Q=4.0567)$ and the sample irradiated with 99 kGy had a small sieve mesh $(Q=3.0130)$, therefore, the highest network density. This confirmed that the $\beta$-irradiation formed a 3D network in iPP (Table 1).

Table 1: Xylene imbibition and X-ray structure analysis

\begin{tabular}{|c|c|c|c|c|c|}
\hline $\begin{array}{c}\text { Irradiatio } \\
\text { n dose }\end{array}$ & $\begin{array}{c}Q \text { after 60 } \\
\text { min in } \\
\text { xylene }\end{array}$ & $X_{\mathrm{X} \text {-ray }}, \%$ & $L_{110}, \mathrm{~nm}$ & $\alpha, \%$ & $\beta, \%$ \\
\hline $0 \mathrm{kGy}$ & 0 & 51.53 & 29.9 & 48.00 & 3.53 \\
\hline $33 \mathrm{kGy}$ & 4.0567 & 50.90 & 29.95 & 47.53 & 3.37 \\
\hline $66 \mathrm{kGy}$ & 3.6432 & 48.20 & 24.9 & 45.44 & 2.76 \\
\hline $99 \mathrm{kGy}$ & 3.0130 & 41.85 & 19.8 & 41.85 & $\mathrm{x}$ \\
\hline
\end{tabular}

Decreased melting $\left(T_{\mathrm{m}}\right)$ and crystallisation temperatures $\left(T_{\mathrm{c}}\right)$, total crystallinity $(X)$ and the presence of $-\mathrm{OH}$ and -CO- groups confirmed that, together with chain crosslinking, the chain degradation also took place.

Typical wide-angle X-ray diffraction patterns (Figure 1) show the characteristic peaks of the $\alpha$-phase and $\beta$-iPP while Table 1 summarises the results of the X-ray analysis. The applied $\beta$-irradiation dose decreased the initial total sample crystallinity X (from $51 \%(0 \mathrm{kGy}$ ) to $42 \%$ (99 kGy)) and the crystallinity of both iPP crystal phases, mostly the $\beta$-phase that completely disappeared

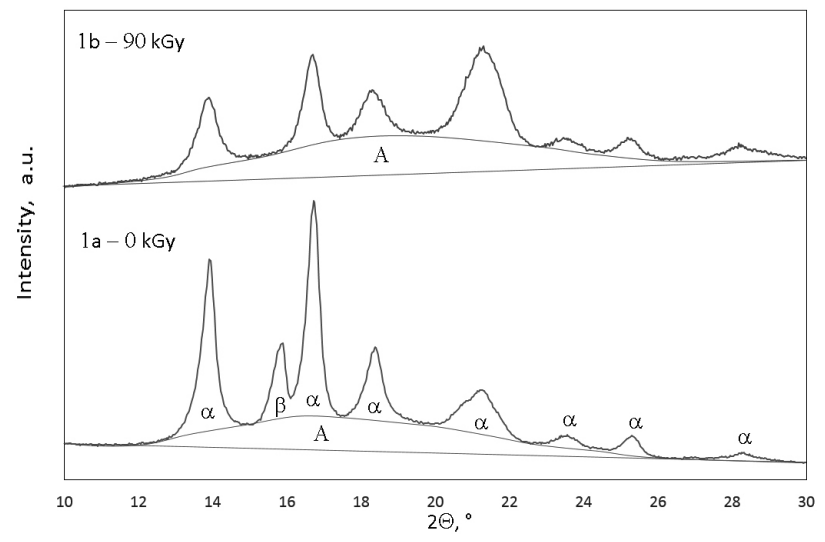

Figure 1: X-ray diffraction patterns of the original non-irradiated sample and sample irradiated by $99 \mathrm{kGy}$ dose.

(confirmed with the diminishing of the $\beta$-300 peak). It is evident that $\beta$ of the iPP phase is more sensitive to the $\beta$-irradiation than the $\alpha$-phase. The amorphous part (A) is affected by the iPP crosslinking and degradation. The highest crystal size of $\alpha$ characterised with $L_{110}$ was found in the case of the non-irradiated sample $(29.9 \mathrm{~nm})$ and at a higher irradiation dose, it decreased (to 19.8 $\mathrm{nm})$.

DSC measurements (Tables 2 and 3 ) confirmed the results of the X-ray analysis indicating that the $\beta$-irradiation had a profound effect on the iPP structure. The crystal peaks and areas confirmed that the $\beta$-irradiation decreased the total crystallinity and the amount of the
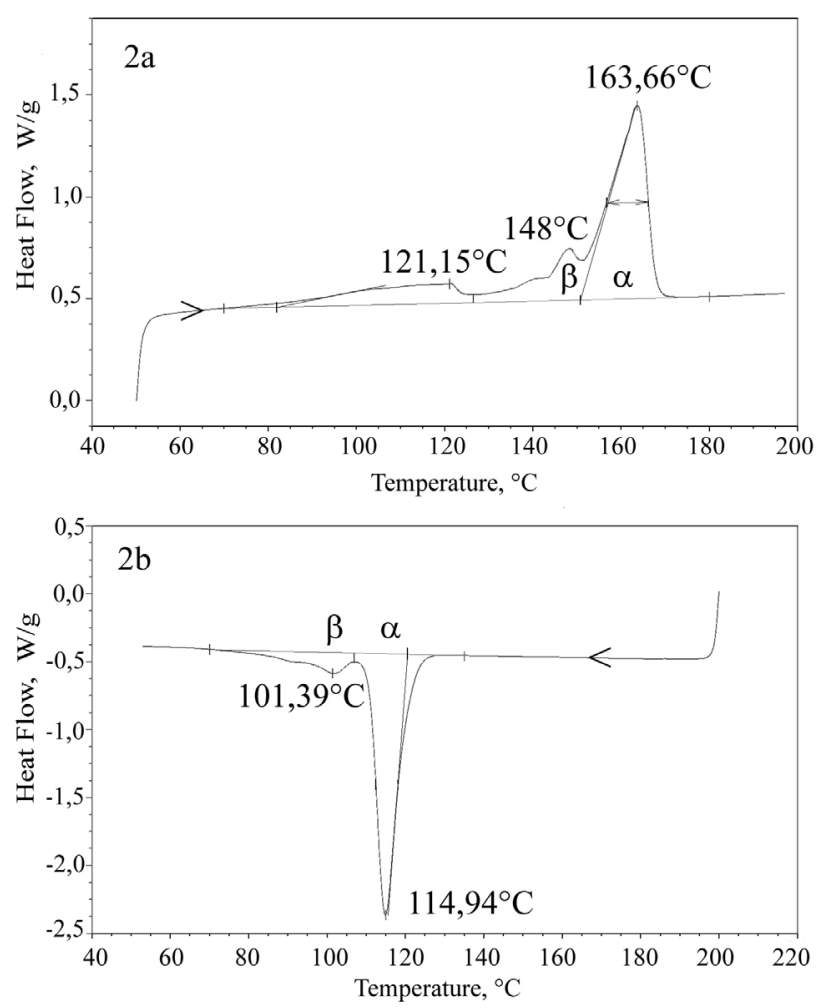

Figure 2: The DSC diagram of the melting (a) and crystallizaton (b) peaks of phases $\alpha$ and $\beta$ for non-irradiated sample 
$\beta$-phase. Besides the peaks of the $\alpha$ - and $\beta$-phases, DSC diagrams (Figures 2a to $\mathbf{2 b}$ ) showed mainly small peaks for the non-irradiated sample in the vicinity of $121^{\circ} \mathrm{C}$, which belonged to another substance than the iPP. For the $\beta$-irradiated samples, these peaks were missing and we assumed that they belonged to the crosslinking agent, as did the small oval structures seen in TEM images (described below).

Table 2: DSC melting

\begin{tabular}{|c|c|c|c|c|c|c|c|c|}
\hline $\begin{array}{c}\text { Irradiat- } \\
\text { ion dose }\end{array}$ & $\begin{array}{c}\text { Melt- } \\
\text { ing }\end{array}$ & $\begin{array}{c}\alpha T_{\mathrm{m}}, \\
{ }^{\circ} \mathrm{C}\end{array}$ & $\begin{array}{c}\Delta H, \\
\mathrm{~J} / \mathrm{g}\end{array}$ & $X_{\alpha}, \%$ & $\beta T_{\mathrm{m}}$, & $\begin{array}{c}\Delta H, \\
\mathrm{~J} / \mathrm{g}\end{array}$ & $X_{\beta}, \%$ & $\begin{array}{c}X_{\text {DSC, }} \\
\%\end{array}$ \\
\hline \multirow{2}{*}{$0 \mathrm{kGy}$} & $1 \mathrm{st}$ & 163.66 & 71.68 & 50.84 & 148 & 3.11 & 5.06 & 55.89 \\
\cline { 2 - 9 } & 2nd & 161.44 & 76.07 & 53.95 & 145 & 2.20 & 3.58 & 57.53 \\
\hline \multirow{2}{*}{$33 \mathrm{kGy}$} & $1 \mathrm{st}$ & 161.89 & 72.41 & 51.35 & 148 & 0.97 & 1.58 & 52.93 \\
\cline { 2 - 9 } & 2nd & 159.95 & 74.23 & 52.65 & 143 & 0.69 & 1.12 & 53.77 \\
\hline \multirow{2}{*}{$66 \mathrm{kGy}$} & $1 \mathrm{st}$ & 159.64 & 72.73 & 51.58 & 145 & 1.98 & 3.22 & 54.80 \\
\cline { 2 - 9 } & 2nd & 157.49 & 73.06 & 51.82 & 142.5 & 0.82 & 1.33 & 53.15 \\
\hline \multirow{2}{*}{$99 \mathrm{kGy}$} & $1 \mathrm{st}$ & 157.97 & 71.83 & 50.94 & 142.3 & 0.61 & 1.00 & 51.94 \\
\cline { 2 - 8 } & 2nd & 155.96 & 71.91 & 51.00 & 142.5 & 0.46 & 0.75 & 51.75 \\
\hline
\end{tabular}

Table 3: DSC crystallization

\begin{tabular}{|c|c|c|c|c|c|c|c|}
\hline $\begin{array}{c}\text { Irradiat- } \\
\text { ion dose }\end{array}$ & $\begin{array}{c}\alpha \mathrm{T}_{\mathrm{c}}, \\
{ }^{\circ} \mathrm{C}\end{array}$ & $\begin{array}{c}\Delta \mathrm{H}, \mathrm{g}, \\
\mathrm{J} / \mathrm{X} \alpha, \%\end{array}$ & $\begin{array}{c}\beta \mathrm{T}_{\mathrm{c}}, \\
{ }^{\circ} \mathrm{C}\end{array}$ & $\begin{array}{c}\Delta \mathrm{H}, \\
\mathrm{J} / \mathrm{g}\end{array}$ & $\mathrm{X} \beta, \%$ & $\begin{array}{c}\mathrm{X}_{\mathrm{DSc}}, \\
\%\end{array}$ \\
\hline $0 \mathrm{kGy}$ & 114.94 & 76.45 & 54.22 & 101.39 & 3.2 & 5.20 & 59.42 \\
\hline $33 \mathrm{kGy}$ & 112.75 & 78.66 & 55.79 & 95.89 & 1.1 & 1.79 & 57.58 \\
\hline $66 \mathrm{kGy}$ & 113.17 & 75.42 & 53.49 & 95.18 & 1.8 & 2.93 & 56.42 \\
\hline $99 \mathrm{kGy}$ & 112.99 & 72.64 & 51.52 & 93.99 & 1.6 & 2.60 & 54.12 \\
\hline
\end{tabular}

$T_{\mathrm{m}}-$ melting temperature, $T_{\mathrm{c}}-$ crystallization temperature, $\Delta \mathrm{H}-$ melting or crystallisation heat

The iPP morphology was studied in several publications. ${ }^{1,8}$ For free-melt crystallised samples, the surface was characterised mostly by lamellar spherulites belonging either to the $\alpha$-or $\beta$-crystal modifications. TEM images of the studied, selectively etched samples are shown in Figures 3a to 3c. The non-irradiated sample (Figure 3a) shows oval structures (dimensions of $0.57 \mu \mathrm{m} \times 0.4 \mu \mathrm{m})$ situated against a lamellar background (the thickness of the lamellae of $0.015 \mu \mathrm{m}$ ). The ovals are not structurally connected to the large spherulite background. We conclude that the ovals represent the particles of the crosslinking agent. This suggestion is confirmed by the fact that the ovals are not present in any further TEM image of the $\beta$-irradiated samples. The $\beta$-irradiation process destroyed this crosslinking agent, and the non-reacted agent was degraded similarly, resembling the parts of the lamellae of the large spherulitic support material.

Figure $\mathbf{3 b}$ shows the iPP irradiated with $33 \mathrm{kGy}$ of the $\beta$-irradiation. The substrate including large thick lamellar blocks is significantly changed and the thick lamellae are divided into small lamellar blocks. In the sample irradiated with a 99-kGy dose (Figure 3c), the oval structures are not present and the lamellar substrate is even more etched and destroyed than before. It is evident that the original morphology was largely changed and destroyed by the $\beta$-irradiation. The lamellar
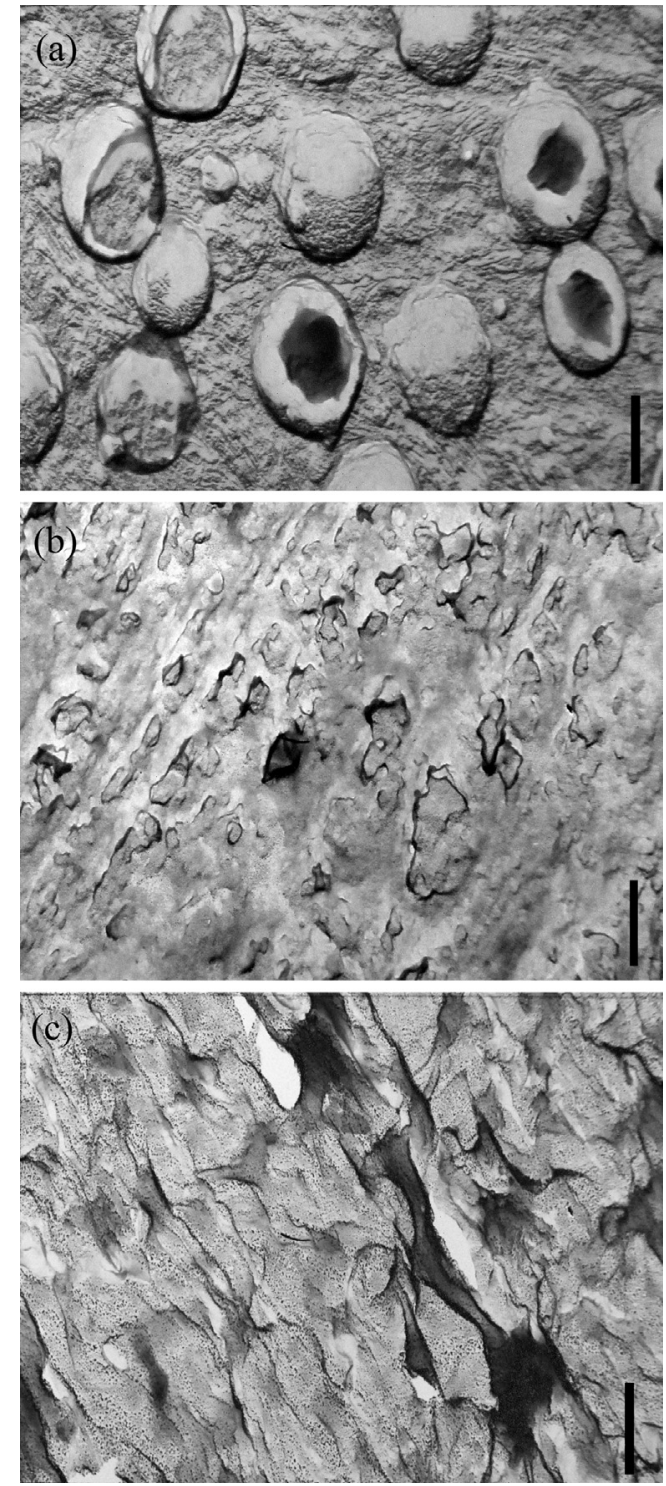

Figure 3: The surface of: a) non-irradiated sample, b) irradiated sample by $33 \mathrm{kGy}, \mathrm{c}$ ) irradiated sample by $99 \mathrm{kGy}$

ends and edges look like melted areas. The question arises whether the small oval lamellae were melted and evaporated or degraded. Also, did the surface parts of the large spherulites undergo the same process?

All the mentioned results confirm that the $\beta$-irradiation caused a significant increase in the sample temperature, which may have led to partial sample melting and recrystallization, sample crosslinking and chain destruction.

\section{CONCLUSIONS}

The effect of the $\beta$-irradiation on iPP was dual: At first, there were chain crosslinking and partial chain degradation due to the presence of $-\mathrm{OH}$ and $-\mathrm{CO}$ - groups in the sample. Simultaneously, the irradiation process warmed up the sample and partially melted or even 
evaporated the oval structures and lamellar ends of spherulites. This process inevitably changed the sample morphology, decreased the total crystallinity values, the melting and crystallisation temperatures. The degradation also decreased the crystal size and diminished the $\beta$-phase amount. The $\beta$-irradiation mostly degraded the free crosslinking agent and the $\beta$-phase of iPP more than the $\alpha$-phase.

\section{Acknowledgment}

This work was supported with a grant from the Tomas Bata University in Zlin, IGA/FT/2017/002, and financed from the funds for specific academic research.

\section{REFERENCES}

${ }^{1}$ B. Lotz, Molecular aspects of structure and morphology of isotactic polypropylene, J. Macromol. Sci., Part B, 41 (2002) 4-6, 685

${ }^{2}$ D. Manas, M. Manas, M. Stanek, M. Danek, Improvement of plastic properties, Arch. Mat. Sci. Eng., 32 (2008) 2, 69

${ }^{3}$ E. Ragan, P. Baron, J. Dobransky, Sucking Machinery of Transport for Dosing Granulations of Plastics at Injection Molding, Adv. Mat. Research, 383-390 (2011), 2813, doi:10.4028/www.scientific.net/ AMR.383-390.2813

${ }^{4}$ M. Ovsik, D. Manas, M. Manas, M. Stanek, M. Hribova, K. Kocman, D. Samek, Irradiated polypropylene studied by microhardness and WAXS, Chemicke listy, 106 (2012), 507

${ }^{5}$ B. Ameduri, Crosslinking in materials science, New York, Springer, 2005

${ }^{6}$ P. Scherrer, Alexander Leroy E., X-ray diffraction methods in polymer science, New York, Wiley-Interscience, 1969, 582

${ }^{7} \mathrm{~J}$. Varga, $\beta$-modification of isotactic polypropylene: preparation, structure, processing and application, J. Macromol. Sci., Part B, 41 (2002), 4-6, 1121

${ }^{8}$ F. Rybnikar, Selective etching of polyolefines. I. Isotactic polypropylene, J. App. Pol. Sci., 30 (1985) 5, 1949, doi:10.1002/app.1985. 070300513 